\title{
COĞRAFí BİLGí
}

\section{SISTEMLERIYLE ATIK \\ TOPLAMA ARAÇLARININ \\ Hacettepe Üniversitesi iktisadi ve Idari Bilimler \\ Fakültesi Dergisi, \\ Cilt 36, Sayı 1, 2018, \\ s. 39-62}

\section{ROTALARININ BELİRLENMESI}

\author{
Kısmet CINGÖZ \\ Arş.Gör., Mersin Üniversitesi \\ İktisadi ve İdari Bilimler Fakültesi \\ İşletme Bölümü \\ kismetcingoz@mersin.edu.tr \\ Ender GÜRGEN \\ Dr.Öğr. Üyesi, Mersin Üniversitesi \\ İktisadi ve İdari Bilimler Fakültesi \\ İşletme Bölümü \\ gurgen@mersin.edu.tr

\section{Burak BEYHAN} \\ Doç.Dr., Mersin Üniversitesi \\ Mimarlık Fakültesi \\ Şehir ve Bölge Planlama Bölümü \\ burakbeyhan@mersin.edu.tr
}

z: Tersine lojistik, özellikle son
y1llarda artan çevresel kaygılar,
kurumsal sosyal sorumluluk ve yasal
düzenlemeler nedeniyle bütün
organizasyonlar için önemli bir çalışma alanı olmaktadır. Bu bağlamda, işletmeler kullanılmış ürünleri/atıkları en kısa sürede, en az maliyetle ve uğraması gereken bütün noktalara uğrayacak şekilde toplama yapmayı amaçlarlar. Özellikle Araç Rotalama Problemleri, bu amaca ulaşmada kullanılan en önemli yöntemlerden birisidir. $\mathrm{Bu}$ çerçevede, bu çalışmanın amacı, ambalaj atığı toplama ve ayırma lisansına sahip bir işletmenin atık toplarken izleyebileceği en uygun rotayı Coğrafi Bilgi Sistemleri yardımı ile belirlemektir. Rotalar belirlenirken OpenJUMP ile gvSIG programları kullanılmış ve işletmenin hizmet verdiği Mersin İli Yenişehir Belediyesi sınırları içerisindeki 9 mahalle için izlenmesi önerilen rotalar belirlenmiştir.

Anahtar Sözcükler: Tersine lojistik, coğrafi bilgi sistemleri, en kısa yol, araç rotalama problemleri. 


\section{DETERMINATION OF THE}

\section{ROUTES OF WASTE COLLECTION VEHICLES USING GEOGRAPHIC INFORMATION SYSTEMS}

\author{
Hacettepe University \\ Journal of Economics \\ and Administrative \\ Sciences \\ Vol. 36, Issue 1, 2018 \\ pp. 39-62
}

\author{
Kısmet CINGÖZ \\ Res.Assist., Mersin University \\ Faculty of Economics and Administrative \\ Sciences \\ Department of Business Administration \\ kismetcingoz@mersin.edu.tr

\section{Ender GÜRGEN} \\ Assist.Prof.Dr., Mersin University \\ Faculty of Economics and Administrative \\ Sciences \\ Department of Business Administration \\ gurgen@mersin.edu.tr

\section{Burak BEYHAN} \\ Assoc.Prof.Dr., Mersin University \\ Faculty of Architecture \\ Department of City and Regional Planning \\ burakbeyhan@mersin.edu.tr
}

bstract: Reverse logistics, especially
in recent years, has become an
important activity for organizations
due to growing environmental concerns, corporate social responsibility and legislative requirements. In this context, firms try to meet some requirements such as the shortest time, minimum cost and visiting all determined collection points while collecting used products/waste at the end of their economic life cycle. Especially, Vehicle Routing Problems are the most important methods used in order to reach these purposes. The aim of this study is determining the best routes using $\mathrm{A}^{*}$ Algorithm of a firm's collection activities which holds a collection and separation license of recyclable packaging waste within the 9 districts of Mersin Yenişehir Municipality by using Geographic Information Systems. The routes were designated via OpenJUMP and gvSIG softwares for nine districts in Mersin which the firm serves.

Keywords: Reverse logistics, geographic information systems, shortest path, vehicle routing problems. 


\section{GíRiş}

Atık azaltımını gerçekleştirmek için, faydalı ömürlerinin sonuna gelen kullanılmış ürünler tamamıyla veya kısmen geri dönüştürülebilir ya da parçalara ayrılabilir, yeniden üretilebilir ve kısmen veya tamamen yeniden kullanılabilir. Atık azaltımının yanı sıra birçok ülke, malzemeler için geri dönüş oranları, satış paketleri için iyileştirmeler ve ürünün geri alınması için yasal zorunlulukları içeren toplam ürün yaşam döngüsünün sorumluluğunu üstlenmesi için ilgili endüstriyi yönetmeliklere tabi tutmaktadır (Agrawal vd., 2015: 76). Bütün bu faaliyetler nihai kullanıcılardan tedarik zincirinin üst kısımlarına doğru malzeme akışına sebep olmaktadır ve durum tersine lojistik olarak adlandırılmaktadır.

Rogers, Tibben-Lembke (1998) tersine lojistiği hammaddenin, yarı mamulün, bitmiş (nihai) ürünün ve bununla ilgili bilginin tüketim noktasından üretim noktasına yeniden değer yaratmak veya uygun bir şekilde imha etmek amaciyla verimli ve uygun maliyetli akışının planlanması, uygulanması ve kontrol edilmesi süreci olarak tanımlamışlardır.

Tersine lojistik süreci ürünlerin tedarik zincirinin sonuna gitmesiyle ve daha sonra geri dönüşüm için istenmesiyle ya da ürünün geri çağrılmasıyla başlar. Uygulamada genel olarak geri dönüşten sorumlu olan bir grup vardır, bunlar ürünü alır ve geri dönüşümünü gerçekleştirir. Diğer bir grup da bunları alıp yeniden satmaya veya yeniden dağıtmaya çalışır. Böylece iade edilen ürünlerden geri dönüşüm değeri yaratılır (De Brito, Dekker, 2002: 6). Bu noktada tersine lojistik ağ tasarımı kavramı önem arz etmektedir. Tersine lojistik ağ tasarımı toplama, iyileştirme ve imha merkezlerinin kapasitesinin, nerede kurulacağının ve sayısının belirlenmesini, her bölümdeki emniyet stoğu miktarının ve bu tesisler arasında taşınacak malzeme miktarının belirlenmesini içerir (Pishvaee $v d .$, 2010: 269).

Fleischmann vd. (2000) göre tersine lojistik ağları, geri dönen ürünler pazarı, geri kazanım tesisleri ve yeniden kullanılan (ikincil) ürünlerin pazarları olmak üzere üç ana bölümden oluşmaktadır. Geri dönen ürünler pazarı bireysel kaynaklardan kullanılmış ürünlerin toplanması ve geri kazanım faaliyetleri için geri kazanım tesislerine gönderilmesidir. Yeniden kullanılan (ikincil) ürünlerin pazarları ise yeniden kullanılabilir ürünleri satın almak isteyen tüketicilerle geri kazanım tesisleri arasındaki bağlantıyı oluşturur. Geri kazanım tesisleri ise geri dönen ürünler pazarı ve yeniden kullanılan ürünler pazarı arasındaki ağdır. $\mathrm{Bu}$ ağ, kullanılmış ürünlerin yeniden kullanılabilir ürünlere dönüşümünün gerçekleştiği değişim sürecini oluşturmaktadır ve yeniden üretim, geri dönüşüm ve yeniden kullanım olarak adlandırılan yeniden işleme şekillerini ve tersine lojistiğin itici güçlerini (ekonomik ve yasal) ve geri kazanım sürecinin sahipliğini (orijinal ekipman üreticileri ve üçüncü partiler) dikkate alarak sınıflandırılmıştır (Fleischmann, 2001: 6). 
CINGÖZ, GÜRGEN, BEYHAN | Determination of the Routes of Waste Collection Vehicles...

Tersine lojistik bir işletmenin bütün fonksiyonlarını etkilemektedir ve verimli bir şekilde uygulanması için dikkatli bir şekilde planlanması gerekmektedir. Ancak çoğu planlama problemleri tersine lojistikle ilgili kaygıları arttırmaktadır. Tersine lojistiğin, geri dönüşüm, yeniden üretim ve yeniden kullanılan malzemelerin ve ürünlerin istenen olumlu çevresel etkilerini fazlasıyla karşılayan ilave lojistik faaliyetleri ile oluşacak gereksiz zararlardan kaçınmak amacıyla dikkatli bir şekilde düşünülmesi gerekir. Fleischmann $v d$. (1997) yaptıkları çalışmada, tersine lojistik sistemleri ile ilgili olarak kimin, hangi görevleri, nerede yapacağı ile ilgili kararların stratejik seviyede alınması gerektiğini ve orta vadeli seviyede ise, yeniden dağıtım sistemlerinin operatörünün ileri ve tersine kanaldaki ilişkiyi belirlemek zorunda olduğunu ifade etmişlerdir. Bu ilişkiye bağlı olarak işlemsel seviyede planlama problemleri arasında ise araç rotalama problemleri yer almaktadır (Fleischmann $v d .$, 1997: 1-17). Araç rotalama problemleri genel olarak bir ăg içerisindeki belirli noktalara en az maliyetle ve en kısa sürede mamul ve hizmet dağıtılmasıyla ilgilenmektedir.

Bu çalışmada ise ambalaj atığı toplama ve ayırma lisansına sahip bir işletmenin, hizmet verdiği bölgelerdeki atıkları en kısa sürede toplayabilmesi için, araç rotalama problemini çözmek amacıyla Coğrafi Bilgi Sistemlerinden (CBS) yararlanılmıştır ve işletmeye atıkları toplarken hangi rotayı izlemesi gerektiğine dair (mahalle bazında) öneride bulunulmuştur. Bu kapsamda, bu çalışmanın yazına temel katkısı atık toplama özelinde tersine lojistik uygulaması içeren bir gerçek hayat probleminin çözümünde Açık Kaynak Kodlu CBS'nin sunduğu eklenti yazılımlarının etkin bir şekilde kullanılabileceğinin gösterilmesidir. $\mathrm{Bu}$ amaç doğrultusunda çalışmanın birinci bölümünde teorik çerçeve ve literatür taraması başlığı altında Araç Rotalama Problemleri ve Coğrafi Bilgi Sistemleri ele alınmış, ikinci bölümde çalışmamızda kullandığımız metodoloji anlatılmış, üçüncü bölümde Mersin Yenişehir Belediyesi sınırları içerisinde mahalle temelli geri dönüşüm aracı rota uygulaması yapılmış, ve dördüncü bölümde ise araç şoförünün örnek bir mahalle için izlemiş olduğu rotanın bizim önerdiğimiz rotayla karşılaştırması yapılarak elde edilen sonuçlar karşılaştırılmıştır. Çalışmamızın son bölümünde ise tartışma ve değerlendirme kısmı yer almıştır.

\section{TEORIK ÇERÇEVE VE LITERATÜR TARAMASI}

Bu çalışmaya konu olan atık toplama işlemiyle ilgili literatürde, Araç Rotalama Problemleri ve CBS aracılı̆̆ıla araçların güzergahlarının belirlenmesini konu alan yayınlara rastlanmıştır. Bu yüzden bu çalışmanın literatür bölümünü iki ana grupta toplanmıştır: Araç Rotalama Problemleri ve CBS. 


\subsection{Araç Rotalama Problemleri}

Rego (2001) ile Toth ve Vigo (2002), araç rotalama problemlerini, bir veya daha fazla depodan, belirli bir müşteri grubuna hizmet etmek için kullanılan araç filosunun optimum rotasının belirlenmesi olarak tanımlamıştır ve bu konuyla ilgili ilk çalışma 1954 yılında Dantzig, Fulkerson ve Johnson tarafından yapılımıstır. Yaptıkları çalışmada geniş kapsamlı bir şekilde, araç rotalama problemlerinin özel bir durumu olarak görülen Gezgin Satıcı Problemini çalışmışlar ve bir çözüm yöntemi önermişlerdir (Ekşioğlu $v d$., 2009: 1473). Daha sonra ortaya çıkan araç rotalama problemlerinin farklı türleri için birçok farklı model ve algoritma önerilmiştir.

Araç rotalama problemlerinde göz önünde bulundurulması gereken amaçlar şu şekilde sıralanabilir (Toth, Vigo, 2001: 4): 1-Kullanılan araçların sabit maliyetine ve gidilecek yola bağlı olan taşıma maliyetlerinin minimizasyonu, 2- Bütün müşterilere hizmet etmek için gereken araç sayısının minimizasyonu, 3- Araç yükü ve seyahat zamanı açısından rotaları dengelemek, 4- Müşteri hizmetleri ile ilişkilendirilen para cezalarının minimizasyonu. Çalışmamızda bu listeden birinci ve üçüncü amaçlara ulaşılmaya çalışılmıştır.

Bunların yanında araç rotalama problemleri pratikte uygulanırken, rota kurulumunda bir çok ek gereksinimlere ve işlemsel kısıtlara ihtiyaç duyulabilir. Örneğin; verilen hizmetlere dağıtım ve toplamanın ikisi birlikte dahil olabilir, her rota için yüklenen miktarın aracın kapasitesini aşmaması gerekir, her bir rotanın uzunluğu önceden belirlenen sınırı aşmamalıdır, müşteriye verilecek hizmet belirlenen çalışma saatleri içinde verilmelidir, müşteri talebi tamamen bilinmeyebilir ve müşteriye verilecek hizmet farklı araçlar arasında paylaştırılabilir (Toth, Vigo, 2002: 487-488).

Araç rotalama problemleri genel olarak bir ağ içerisindeki belirli noktalar arasında mal ve hizmet dağııımı ile ilgilenmektedir ve araç rotalama problemlerine olan ilgi gün geçtikçe artmaktadır. $\mathrm{Bu}$ da araç rotalama problemlerini farklı alanlarda kullanılabilme firsatını yaratmaktadır. Örneğin, ürün ve hizmetlerin bir veya daha fazla sayıdaki depodan, çeşitli müşteri adreslerine dağıtımı, üretim planlaması ve hammadde, yarı mamul ve mamullerin fabrikalar arası taşınması, stok planlaması ve ürünlerin satış yerlerine sevkiyatı, havayolu şirketleri ile yolcu taşınması, para dağıtımı, benzin ve mazot dağıtımı, çöp toplanması ve taşınması gibi (Düzakın, Demircioğlu, 2009: 71).

Araç rotalama problemleri, çeşitli kriterlere göre kendi içinde farklılaşmaktadır. $\mathrm{Bu}$ kriterler genellikle kısıtların, araçların, müşterilerin, yolların ve rotaların özelliklerine göre ortaya çımaktadır. Araç rotalama problemi bu kriterlere göre aşağıdaki şekilde sınıflandırılmıştır. Araç rotalama problemleri, çeşitli kriterlere göre kendi içinde farklılaşmaktadır. Bu kriterler genellikle kısıtların, araçların, müşterilerin, yolların ve rotaların özelliklerine göre ortaya çıkmaktadır. Araç rotalama problemi bu 
CINGÖZ, GÜRGEN, BEYHAN | Determination of the Routes of Waste Collection Vehicles...

kriterlere göre şu şekilde sınıflandırılmıştır: dinamik veya statik araç rotalama problemi türleri, rotaların durumuna göre araç rotalama problemi türleri, kısıtlarına göre araç rotalama problemleri türleri, yolların durumuna göre araç rotalama problemleri ve dağıtımlı ve toplamalı araç rotalama problemleri. (Erol, 2006: 11-12; Kuşçu, 2009: 7; Wassan vd., 2008: 369).

Araç rotalama problemlerine uygun çözümler bulmak gün geçtikçe zorlaşmaktadır. Çünkü rotalamada kullanılan kısıtların farklılığı ve fazlalığı araç rotalama problemlerini daha da karmaşı bir hale getirmektedir. Araç rotalama problemlerini çözmek için geliştirilen yöntemler Tablo 1'de gösterilmektedir (Erol, 2006).

Tablo 1. Araç Rotalama Problemleri İçin Geliştirilen Yöntemler (Erol (2006)'dan uyarlanmıştır.)

\begin{tabular}{|c|c|}
\hline \multicolumn{2}{|c|}{ Araç Rotalama Problemle ri İçin Ge liştirilen Yönte mler } \\
\hline Sezgisel Algoritmalar & Metasezgisel Algoritmalar \\
\hline 1)İyileş tirmeli Sezgis el Algoritmalar & 1)Tavlama Benzetimi Algoritması \\
\hline - Tek Rota İyileştirmeli Sezgisel Algoritmalar & 2)Tabu Arama Yönte mi \\
\hline - Çok Rota İyileştirmeli Sezgisel Algoritmalar & 3)Karınca Kolonisi Optimizas yon Yöntemi \\
\hline 2)Yapıs al Sezgisel Algoritmalar & 4)Genetik Algoritmalar \\
\hline - Clarke ve Wright Tasarruf Algoritması & 5)Yapay Sinir Ağları \\
\hline · Eşleme Tabanlı Tasarruf Algoritması & \\
\hline - Siralı Ekleme Sezgisel Algoritması & \\
\hline · En Kısa Yol Yöntemi & \\
\hline 3) Çok Aşamalı Sezgisel Algoritmalar & \\
\hline · İlk Grupla Sonra Rotala Yöntemi & \\
\hline - İlk Rotala Sonra Grupla Yöntemi & \\
\hline
\end{tabular}

Literatürde tersine lojistikte araç rotalaması ile ilgili tamsayılı doğrusal programlama (Dethloff, 2001; Güvez vd., 2012) ve karma tamsayılı doğrusal programlama (Kaçtığlu, Şengül, 2010; Madankumar, Rajendra, 2016; Soysal vd., 2015) gibi matematiksel modeller kullanıldığ gibi; yerel arama (Li vd., 2016; Li vd., 2015; Zchariadis, Kiranoudis, 2011), genetik algoritma (Bae, Moon, 2016; Liu vd., 2013; Tasan, Gen, 2012) ve tabu arama (Montané, Galvao, 2006) gibi birçok farklı algoritma kullanılıştır.

Çalışmamıza konu olan araç rotalama sisteminde, atıklar müşterilerden yani nihai kullanıcılardan toplanmakta olup, müşterilere bir dağıtımda bulunulmamaktadır. $\mathrm{Bu}$ yüzden çalışma Dağıtımlı ve Toplamalı Araç Rotalama Problemleri olarak ele alınmayıp, sadece toplamalı bir sistem olarak tanımlanmış ve Kapalı Uçlu Araç Rotalama Problemi olarak ele alınmıştır. Ayrıca çalışmada araç rotalama problemlerini 
çözmek için Yapısal Sezgisel Algoritmalardan En Kısa Yol Yöntemi (A* Algoritması) kullanılmıştır. Bu yöntem sadece bir başlangıç noktasının ve bir varış noktasının olduğu şebekelerde rotalama işlemi yapmak için kullanılmaktadır. En kısa yol yöntemi ile bir şebeke içerisinde bir başlangıç noktasından bir varış noktasına ulaşmak için en kısa mesafeyi bulmak amaçlanmaktadır.

\subsection{Coğrafi Bilgi Sistemleri}

$\mathrm{Bu}$ çalışmaya konu olan araç rotalama CBS aracılığıyla, atık toplama araçlarının belirlenen bütün noktalara en kısa yolu kat ederek uğraması ve atık toplama merkezine ulaştırmasıdır.

CBS, dünya üzerindeki referanslanmış verileri toplayan, sınıflandıran, kontrol eden, bütünleştiren, yöneten, analiz eden ve görselleştiren bir sistemdir (Fazal, 2008: 7). Kalkancı (2009) ise coğrafi bilgi sistemlerini dünya üzerindeki karmaşı sosyal, ekonomi ve çevre gibi sorunların çözümünde mekana dayalı karar verme süreçlerinde kullanıcılara yardımcı olan, büyük hacimli coğrafi verilerin toplanması, depolanması, işlenmesi, mekansal analizi, sorgulaması ve sunulması işlevlerini yerine getiren donanım, yazılım, coğrafi veri yöntemler bileşenlerinden oluşan bir bütün olarak tanımlamışır.

Öncelikle mekansal verileri farklı yazılım programları yardımıyla bilgisayar ortamına aktarıldığ CBS'de, bunu gerçekleştirmek için ilgili bilgisayar donanımına ihtiyaç duyar (Alevkayalı, 2012: 9). Ayrıca oluşturulacak coğrafi bilgi sistemlerinin başarıya ulaşması için kullanıcının amacına göre tasarlanmasını sağlayacak yöntemlere ve uzman kişilere ihtiyaç duyulur. Bu ihtiyaç duyulan veri, yazılım, donanım, yöntem ve uzman kişiler de coğrafi bilgi sistemlerinin unsurlarını oluşturmaktadır.

CBS'de iki tür mekânsal veri vardır; vektör veri ve raster veri. Vektör veri; nokta, çizgi ve poligon aracılı̆̆ıla ile coğrafik özellikleri gösteren yöntemdir. Bilgisayar Destekli Çizim (Computer Assisted Drawing - CAD) yazılımları ile oluşturulan veriler, vektör veri örnekleridir ve vektör verilerde mekansal veriler $\mathrm{x}$ ve y koordinat çiftleri şeklinde saklanabilmektedir. Raster veri ise pikseller-hücreler aracılı̆̆ıla coğrafik özellikleri gösteren bir yöntemdir (Fazal, 2008: 92). Uydu aracilığıyla ya da uçaktan çekilen fotoğraflar raster veriye örnek gösterilebilir.

CBS'de kullanılan farklı yazılım programlarına örnek olarak; Arc Map, MapInfo, GRASS, Quantum GIS, SAGA, OpenJUMP, gvSIG ve KOSMO vs. verilebilir. Bu programlardan bazıları açık kaynak kodlu programlardır ve ücretsizdir. Özgür ve Açık Kaynak Kodlu (ÖAKK) CBS yazılımlarının en temel özelliklerinden bir diğeri olan geliştirmeye ve değişikliklere açık mimarileri göz önünde bulundurulduğunda, pek çok ÖAKK CBS uygulama yazılımında eklenti yazabilme 
olanağı bulunduğu görülmektedir (Beyhan $v d$., 2010: 47). Örneğin, OpenJUMP'da hem Java kullanılarak rahatlıkla eklenti yazılabilmekte, hem de BeanShell ve Jtyhon konsolu kullanılarak, yazılan kodlar anında çalı̧̧ııılabilmekte ve aynı zamanda, yazılan basit kodlar, Java derleme sürecinden geçirilmeden, birer eklenti biçiminde çalıştırılabilmektedir (Beyhan vd., 2010: 54). Benzer şekilde çok daha gelişkin olan QGIS ve gvSIG gibi Açık Kaynak Kod (AKK) CBS yazılımlarında eklenti oluşturma olanakları bulunmaktadır. Pythonda yazılan kodlar rahatlıkla eklenti şeklinde QGIS'e aktarılabilmekte ve istenildiği zaman çalıştırılmaktadır.

Bu çalışmada kullanılan OpenJUMP ve gvSIG birer AKK yazılımdır. Her iki yazılımın da AKK olması yanısıra temel avantajı ücretsiz birer yazılım olmaları ve analiz ayarlarının daha basitleştirerek sonuç verilmesi/toplanmasıdır. Hem OpenJUMP hem de gvSIG Java dilinde yazılmış olup, gvSIG büyük ölçüde İspanya hükümeti tarafından, OpenJUMP ise Kanada hükümeti tarafından finanse edilmiştir. İki yazılım da herhangi bir coğrafi bilgi sistemleri yazılımında olması gereken ve en temel teknik özelliklerden biri olarak kabul edilen vektörel veri sonuçlu mekânsal işlemler ve sorgulamalar konusunda en başarılı programlar arasında yer almaktadır (Beyhan $v d$., 2010: 53). Hem gvSIG hem de OpenJUMP'da Jtyhon konsolu kullanılarak, yazilan kodlar anında çalıştırılabilmekte ve aynı zamanda, yazılan basit kodlar, birer eklenti biçiminde çalıştırılabilmektedir. Bu çalışmada da ağırlıklı olarak OpenJUMP'in Planar Graph ve özellikle gvSIG'in Network eklentisi kullanılarak analizler yapılmıştır.

Tersine lojistikte araç rotalama problemlerinin çözümünde yazılım programlarının kullandığı algoritmalar (Dijikstra, Gezgin Satıcı Problemi, En kısa yol yöntemi gibi) farklılıklar gösterse de coğrafi bilgi sistemlerinin kullanıldığı çalışma sayısı oldukça azdır. Apaydın vd., (2004), Trabzon ilinde katı atıkların toplanması için kullanılan araç rotalarını optimize etmeyi amaçladıkları çalışmada en kısa güzergahı belirlemek için Route View programını kullanmışlardır. Yapılan rotalama işlemi sonucunda mevcut güzergah ile optimize edilen güzergah kıyaslandığında aracın kat edeceği yol \%20 oranında azalmış ve katı atık toplama aracının sağa/sola dönüş sayısı da $\% 30$ oranında azalmıştır.

Banar $v d$. ., (2008) Eskişehir ilinde tıbbi atıkların toplanması ve taşınması için araç rotalama problemini ele aldıkları çalışmalarında CBS'den yararlanarak araç rotalarını belirlemişlerdir. Çalışma sonucunda tıbbi atık toplama rotalarının mesafesinde haftalık \%3.8'lik bir azalma sağlamışlardır.

Ghose $v d$., (2006) West Bengal State (Hindistan)'in Asansol yerel yönetimi için uygun toplama, saklama ve imha planı tasarlamak ve geliştirmek için yaptıkları çalışmada nüfus yoğunluğu, atık toplama kapasitesi, yol ağı, yol ve toplama kutusu türü ve toplama araçları gibi parametrelere bağlı olarak bir GIS rotalama modeli 
geliştirmişlerdir. Önerilen modeli katı atıkları çöp sahasına taşımak için minimum maliyet/mesafe etkin toplama yollarını izlemek için kullanmışlardır.

Nayati (2008) otobüs durağ yerleşimine, en hızlı tasarıma ve otomatik araç konumu belirleme amacıyla en güvenli otobüs rotası belirlemeye yardım edecek okul taşıma yönetim sistemi tabanlı bir CBS yaratmak amacıyla yaptığı tez çalışmasında bir prototip model geliştirmiş ve modeli geliştirirken GIS yazılımı ArcGIS ve Network Analyst'den faydalanmıştır.

\section{METODOLOJI}

\section{1. Çalışmanın Amacı}

Bu çalışmada, her bir aracın kendi bölgesindeki ambalaj atıklarını topladığı göz önünde bulundurularak ve her mahalledeki her sokağa uğradıkları varsayımı altında araç rotalama problemleri çözüm yöntemlerinden biri olan yapısal sezgisel algoritmalardan en kısa yolun bulunabilmesi için A* algoritması ile çalışmaya konu olan firmaya tahsis edilen Mersin İli Yenişehir ilçesindeki 9 mahalleye hizmet veren araçların hangi rotayı takip etmesi gerektiği belirlenmiştir. Firma, bu bölge için 3 araç ayırmış olup Mersin Forum Alışveriş Merkezi'nin iş yoğunluğu fazla olmasından kaynaklı olarak Forum'a hizmet eden daimi 1 araç tahsis edilmiş olup, bu aracın rotası sabit olduğundan, çalışmamız diğer iki aracın uğramış oldukları mahaller için en uygun rotalarının belirlenmesi olarak hazırlanmıştır.

\section{2. Çalışmanın Kapsamı ve Veri Toplama Süreci}

Mersin Yenişehir Belediyesi, belediye sınırları içerisinde geri dönüşüm atıklarının toplanması için, bölgede faaliyet gösteren, toplama ve ayırma lisansına sahip olan 3 firmaya bölgeler tahsis etmektedir. Firmalara bölgeler tahsis edilirken mesken ve iş yeri sayılarıyla, alış-veriş merkezleri, hastane, okul ve kamu binası sayıları dikkate alınmaktadır.

Uygulamanın gerçekleştirildiği işletme ise bu üç firmadan biri olup 1995 yllında Mersin'de yasal standartlara uygun geri dönüşüm tesisi kurarak sektörde faaliyete başlamış ve daha sonra Adana ve İzmit'te benzeri tesisler kurmuştur. Bu tesislerde genellikle perakende alımlarıyla birlikte, yan kuruluşları ile Türkiye çapında ve yurtdışından toptan geri dönüşüm maddelerinin pazarlanmasında aracı kurum görevini üstlenmektedir. 2008 yllında Çevre ve Orman Bakanlığı Yönetmeliği kapsamında ambalaj atıkları toplama ve ayırma lisansı alan işletme bu sektörde Türkiye'de ilk olarak; ISO 9001: 2000 Kalite Yönetim Sistemi ve ISO 14001 Çevre Yönetim Sistemleri sertifikası almıştır. Şimdiki kapasitesi aylık ortalama 4000 ve yıllık 48000 ton olup, toplanılan ambalaj türleri; cam, metal, plastik, kâğıt/karton ve kompozittir. 
CINGÖZ, GÜRGEN, BEYHAN | Determination of the Routes of Waste Collection Vehicles...

Çalışma kapsamında, atık toplama ve ayırma lisansına sahip firmadan, hizmet verilen mahallelerin bilgisi, çalışan sayısı; araçların sayısı, kapasiteleri ve hangi mahallelere hangi gün gittiği ile her mahalledeki alış-veriş merkezi, okul, işyeri, hastane, kamu kurumu sayıları gibi toplu yaşam ve iş alanları bilgileri elde edilmiştir. Firma sadece araçlara hangi gün hangi mahalle ve/veya kurum/kuruluşlara gideceği bilgisini vermekte, mahalle içi toplama rotasını sürücünün inisiyatifine bırakmaktadır. En kısa yolu kat edecek güzergâhın seçimi sürücüye bırakılması, aslında firma için maliyetlerin azaltması noktasında belirsizliğe neden olmaktadır. Bu kapsamda, çalışmamızın amacı araçlar için en uygun rotayı belirleyerek, atıkların toplanması sırasında uğranılacak noktaların sırasının bir standarda oturtarak değişken maliyetler kapsamında yer alacak akaryakıt maliyetlerini en aza indirmeye çalışmaktır. İşletme, Mersin ilinin Yenişehir, Toroslar, Akdeniz, Silifke, Pozantı Belediyelerine hizmet vermektedir. Bu çalışmanın uygulama kısmında sadece Yenişehir Belediyesi göz önünde bulundurulmuştur. İşletme Mersin İli Yenişehir İlçesinde bulunan 23 mahalleden 9 mahalleye hizmet vermektedir ve bu hizmet verilen mahalleler işletme tarafından üç bölgeye ayrılmaktadır. İş yeri sayısının fazla olması dolayısıyla ambalaj atığı miktarının fazla olduğu Mersin Forum AVM işletme tarafından bir bölge olarak kabul edilmektedir. Birinci bölge sadece Mersin Forum AVM'den oluştuğu için yani araç sadece bu AVM'ye gidip geldiği için (sokak sokak dolaşmadığı için) çalışmaya dahil edilmemiştir. İkinci Bölge; Palmiye Mahallesi, Gazi Mahallesi, İnönü Mahallesi, Piri Reis Mahallesi ve Dumlupınar Mahallesi’nden oluşmaktadır. Üçüncü Bölge; Güvenevler Mahallesi, Barbaros Mahallesi, Menteş Mahallesi ve Aydınlıkevler Mahallesi'nden oluşmaktadır. İşletme bünyesinde bulunan 1 No'lu araç 2. Bölgeye, 2 No'lu araç ise 3. Bölgeye hizmet etmektedir. Firmaya ait 3. Araç sadece Mersin Forum AVM'ye hizmet etmekte olup, atıkların toplanacağı ve boşaltılacağı noktalar arasında başka bir yerde durmayacağı için çalışma kapsamı dışında tutulmuştur. Araçların günlere göre toplama yaptıkları mahalleler Tablo 2'de gösterilmiştir.

Tablo 2. Günlere Göre Araçların Toplama Yaptıkları Yerler

\begin{tabular}{|l|l|l|}
\hline & 1 No'lu Araç & 2 No'lu Araç \\
\hline Pazartesi & Piri Reis Mahallesi ve Esnaflar & Aydınlık Evler ve Marketler \\
\hline Salı & Okullar, Eczaneler, Hastaneler & Güven evler Mahallesi, Menteş Mahallesi ve Okullar \\
\hline Çarşamba & Marketler & Dershaneler, Marketler ve Güven evler Mahallesi \\
\hline Perşembe & Gazi Mahallesi, İnönü Mahallesi, Palmiye Mahallesi & Barbaros Mahallesi ve Kamu Kurumları \\
\hline Cuma & Yenişehir Okulları & Okullar ve Marketler \\
\hline Cumartesi & Dumlupinar Mahallesi ve Dershaneler & Güven evler Sitesi, Dershaneler ve Okullar \\
\hline
\end{tabular}

Şekil 1'de çalışmaya konu olan 9 mahallenin farklı renklerde işaretlendiği program görüntüsü yer almaktadır. Şekilde Yenişehir ilçesinin çalışmaya dahil edilen dokuz mahallesi farklı renklerde noktalarla gösterilmiştir 


\section{Şekil 1. gvSIG Programından Çalışma Ekranı Görüntüsü}

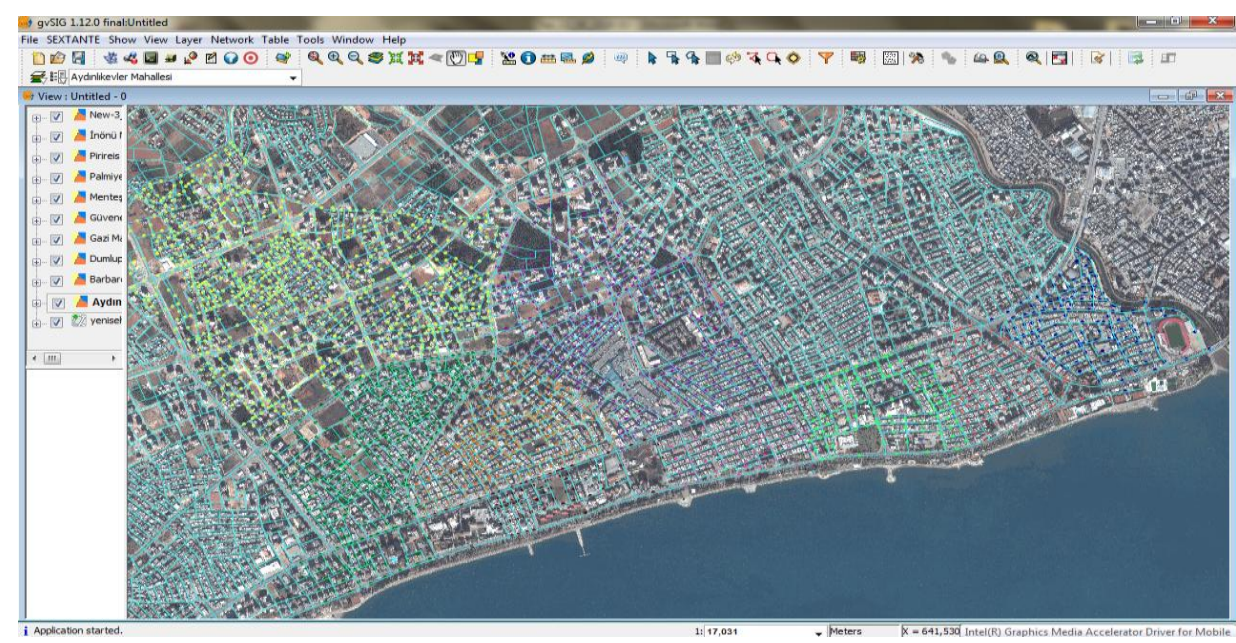

Araçların hizmet ettikleri mahallelerden topladıkları ortalama günlük atık miktarı Tablo 2'de gösterilmektedir. Bu veri, işletmenin 2013 yılına ait 1 yıllık verisi olup, araçların atıkları topladıktan sonra işletmeye-boşaltma için gitmeden önce tartıldığı Yenişehir Belediyesi Teknik Hizmetler Biriminden elde edilmiştir.

Tablo 3. Araçların topladıkları Günlük Ortalama Atık Miktarı (Kg)

\begin{tabular}{|l|l|l|}
\hline & $\mathbf{1}$ No'lu Araç & 2 No'lu Araç \\
\hline Pazartesi & 1437,6 & 1401,33 \\
\hline Salı & 1352,17 & 1626,67 \\
\hline Çarşamba & 1490,67 & 1446,84 \\
\hline Perşembe & 1368,7 & 1426,34 \\
\hline Cuma & 1488 & 1582,63 \\
\hline Cumartesi & 1622,86 & 1393,33 \\
\hline
\end{tabular}

Bu tabloya göre günlük ortalama en çok ambalaj atığının toplandığı mahalle ve yerleşim mekanları Güvenevler Mahallesi, Menteş Mahallesi ve Okullar iken günlük ortalama en az ambalaj atığının toplandığı yerler Okullar (Piri reis, Gazi, İnönü, Dumlupınar ve Palmiye Mahallelerindeki), Eczaneler, Hastanelerdir. 1 No'lu Araç Pazartesi günü hizmet ettiği Piri Reis Mahallesi ve Esnaflardan ortalama 1437,60 kg, Salı günü hizmet ettiği Okullar, Eczaneler, Hastanelerden 1352,17 kg ambalaj atığı toplamaktadır. Aynı şekilde 2 No'lu Araç Pazartesi günü hizmet ettiği Aydınlık evler Mahallesi ve okullardan 1401,33 kg, Salı günü hizmet ettiği Güven evler Mahallesi, Menteş Mahallesi ve Okullardan 1626,67 kg ambalaj atığı toplamaktadır. 
CINGÖZ, GÜRGEN, BEYHAN | Determination of the Routes of Waste Collection Vehicles...

İşletme bünyesinde 3 adet atık toplama aracı bulunmaktadır ve her bir aracın kapasitesi 4 tondur. Araçlar 08:00-18:00 saatleri arasında (günde 10 saat) hafta içi her gün, hafta sonu ise sadece cumartesi günü çalı̧̧maktadırlar. Burada her araç sadece bir bölgeye hizmet etmektedir. 2. Bölgede ve 3. Bölgede görev alan araçlarda ikişer kişi çalışmaktadır ve biri şoför diğeri ise toplayıcı olarak hizmet etmektedir.

Araçlar topladıkları ambalaj atıklarını toplama merkezine götürüp boşaltmadan önce Yenişehir Belediyesi Teknik Birimler Hizmet Binasına götürmektedir. Burada araçların topladığı günlük ambalaj atığı miktarı tartıldıktan sonra firmaya ait toplama ve ayırma merkezine götürülüp boşaltılmaktadır. Bu sayede Yenişehir Belediyesi, Çevre ve Orman Bakanlığı ile yaptığı ortak çalışma kapsamında toplanan ambalaj atığı miktarını kontrol etmektedir.

Araç rotalama probleminin çözümü ile işletmenin hizmet verdiği 13 atık toplama noktasının 8'i için araçların takip edebileceği en kısa rota hesaplanmıştır. Rotalama yapılmayan 5 atık toplama noktası 2. Bölgede okullar, hastaneler, eczaneler; marketler ve Yenişehir okulları ile 3. Bölgedeki dershaneler, marketler ile okullar ve marketlerdir. Araç Rotalama Problemleri işletmenin var olan sistemine göre hesaplanmıştır.

\section{TERSINE LOJISTIK AĞLARINDA ARAÇ ROTALAMA PROBLEMI UYGULAMASI}

Çalışmada kullanılan yol ağına ilişkin vektör verisi OSM (OpenStreetMap) verilerinin shp formatta indirebildiği Geofabrik'in internet sitesinden (http://download.geofabrik.de/) temin edilmiştir. Bu çalışmamızda, topolojik olarak güncel, nitelikli ve doğru veriyi içerdiği için OSM veritabanından temin edilen yol ağı kullanılmıştır. OpenStreetMap herkesin kullanımına açık bir veridir ve OSM Vakfı (OSMF) tarafından desteklenmektedir. Çalışma kapsamında ilk olarak Open-JUMP programında Yenişehir ilçesinin .shp formatındaki haritasında (katman) düzenlemeler yapılarak harita en kısa yol problemi için uygun hale getirilmiş̧ir. Assl rotalama işlemi gvSIG'de yapılmasına karşın, burada kullanılan Network eklentisinin üzerinde çalışabileceği bir vektör katman oluşturmak için her bir yol parçasının ayrı çizgiler (edge) şeklinde birbirine bağlandıkları noktalar arasında süreklilik arz edecek biçimde yeniden düzenlenmesi gerekmektedir. Bunun için yol ağı verisinin yer aldığı vektör katman OpenJUMP'ta Planar Graph eklentisi kullanılarak topolojik düzeltmeler yapılmış ve ardından yine aynı CBS yazılımında tüm yol ağı parçalarını oluşturan segmentlere bölünerek gvSIG'deki Network eklentisin kullanımına uygun hale getirilmiştir. Bu işlemler yapılmadan önce yine OpenJUMP'ta verinin iyileştirilmesine yönelik pek çok düzeltme işlemi de yapılmıştır (örneğin kavşak noktalarında birbirinden kopuk olan yol parçacıkları birbirine bağlanmış v.b. düzeltmeler yapılmıştır). Şekil 2 OpenJUMP programı yardımıyla düzenlenen, Yenişehir ilçesinde rotalama yapmak için gerekli olan yol verisini göstermektedir. Burada iki katman vardır. İlki analize hazır 
halen getirilen ve turkuaz renk ile gösterilen yol ağına ilişkin vektör veri katmanı, ikincisi ise Yenişehir Belediyesi'nden alınarak oluşturulan raster veri katmanıdır.

\section{Şekil 2. Yenişehir İlçesi Yol Verisi}

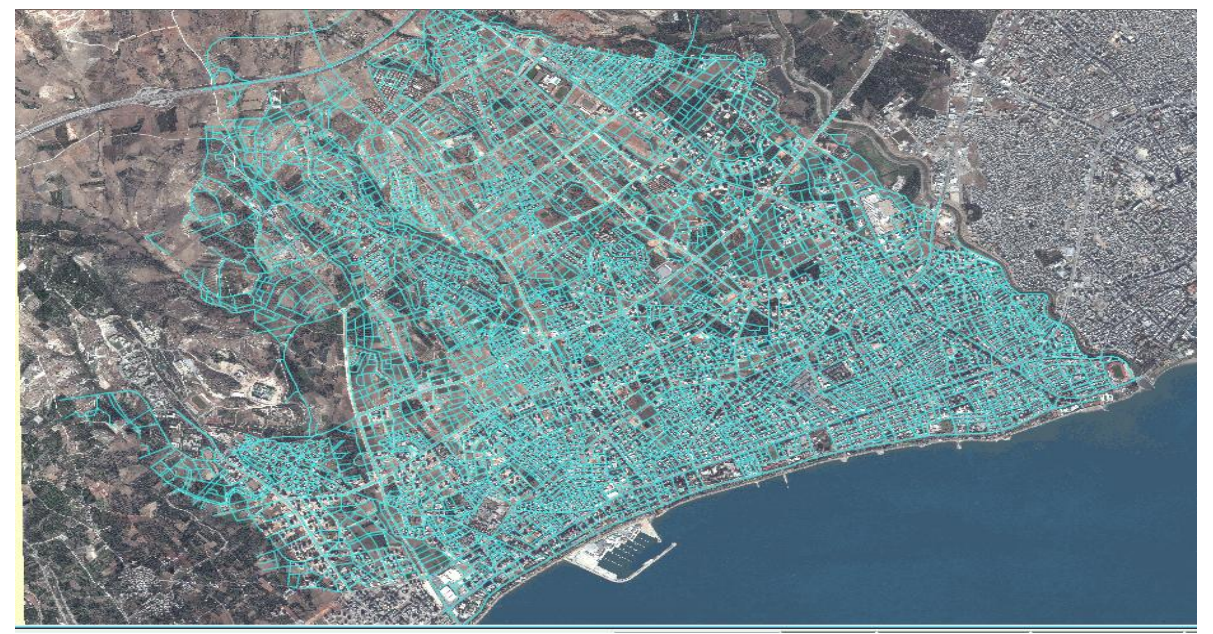

En kısa güzergahın belirlenmesi için önce gvSIG programının "Network" eklentisinin "Create Network" modülü yardımıyla vektör katman programa tanıtılmış, sonrasinda "Manage Route" modülü ile en kısa yolunun bulunması istenilen mahalledeki sokaklar sisteme tanıtılmış ve her sokak üzerindeki blokların orta noktasına düğümler atılması sağlanmıştır. Düğümler sistem tarafından atanmaktadır. Birden fazla noktaya uğrayarak rotalama yapmayı sağlayan "Shortest Path" modülünün temel aldığı algoritma yani A* Algoritması Tablo 4 'te gösterilen kod ile çalışmaktadır.

Tablo 4. A* Algoritması Pseudo Kodu

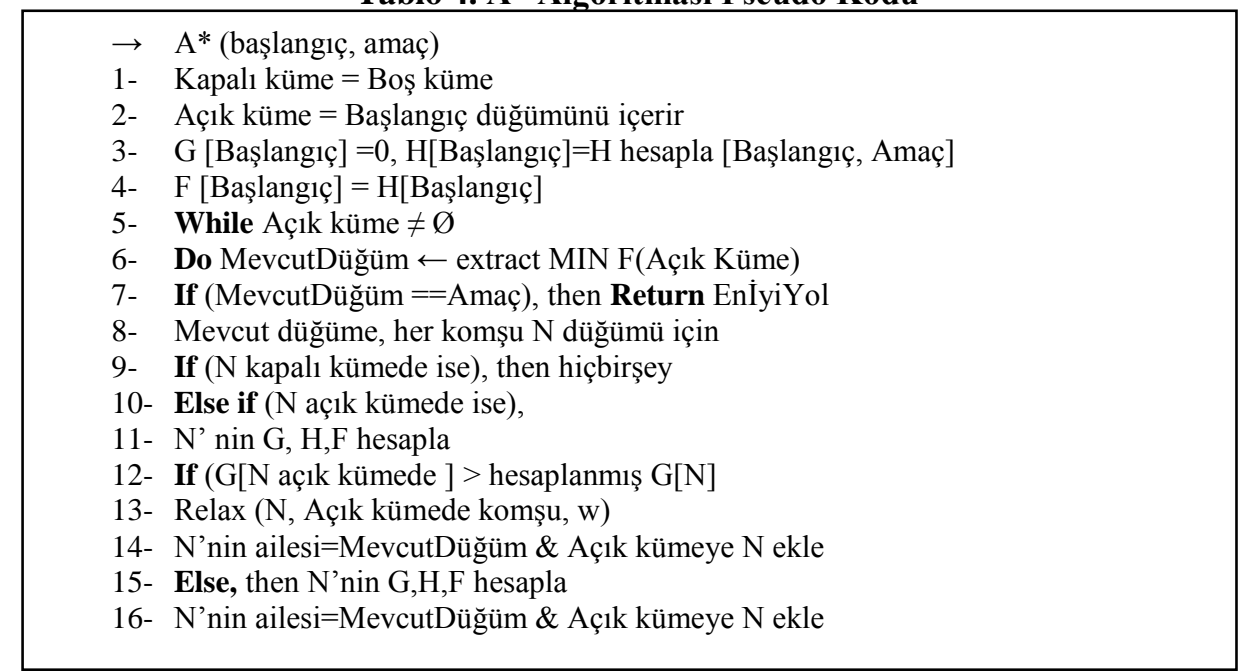


CINGÖZ, GÜRGEN, BEYHAN | Determination of the Routes of Waste Collection Vehicles...

Algoritmada birinci satırdan dördüncü satıra kadar başlangıç şartları gösterilmiştir. Açık küme, bilinen düğümler kümesi olarak tanımlanmaktadır. Açık kümedeki düğümler mevcut düğümlerin komşu dügüumleridir ve mevcut dügüum olabilirler. Kapalı küme ise mevcut düğümlerden oluşan dügüumler kümesidir. En kısa yolu bulmak için, G, H ve F'nin değerleri kullanılır. G'nin değeri başlangıç düğümünden mevcut düğüme kadar mevcut en kısa mesafedir. H'nin değeri mevcut dügüumden hedef düğüme kadar olması tahmin edilen mesafedir ve F'nin değeri ise $\mathrm{G}$ ve $\mathrm{H}$ değerlerinin toplamıdır. Beşinci satırda gösterildiği gibi $\mathrm{A}^{*}$ algoritması açık kümede eleman kalmayana kadar yani açık küme boş küme olana kadar çalıştırılır. Eğer açık küme boş değilse "then EXACT-MIN-F" fonksiyonu çalıştırılır. Bu açık kümede en küçük $\mathrm{F}$ değerine sahip olan mevcut bir düğüm olur. Sonra bu mevcut düğüm açık kümeden silinir ve kapalı kümeye eklenir. Bundan sonraki satır mevcut dügüumün amaç düğümle aynı olup olmadığını kontrol eder. Eğer mevcut düğüm amaç düğümü ise, en kısa yol bulunmuştur ve çözüme geri dönülür. Eğer mevcut düğüm amaç dügümüne eşit değil ise, Komşu N düğümleri için dokuzuncu, onuncu ve on beşinci satırlarda yer alan durumlardan biri gerçekleşir. Eğer komşu düğüm $\mathrm{N}$ kapalı kümede ise hiçbir şey yapılmaz (dokuzuncu satır). Diğer iki durum G, H ve F değerlerini hesaplayan genel bir fonksiyondur. İki durum arasındaki fark bir gevşetme yapmaya ihtiyaç olup olmamasıdır. Eğer komşu düğüm açık kümedeyse, gevşetmeye ihtiyaç vardır. Bu gevşetme $G$ değerini geliştirme olasılığını kontrol eder. Gevşetmeden sonra eğer gevşetmede G'nin hesaplanan değeri G'nin daha önceki değerinden küçükse, G’nin değeri daha küçük bir değerle değişebilir (On ikinci ve on üçüncü satır) (Hart vd., 1968; Seo vd., 2009: 1499-1500). gvSIG programının network eklentisinin shortest path modülünün $\mathrm{A}^{*}$ algoritması ile çalıştığına dair herhangi bir yazılı kaynak yoktur. $\mathrm{Bu}$ sebeple programın resmi sitesindeki iletişim bilgileri aracılığıyla (http://www.gvsig.com/) e-posta gönderilmiş ve $\mathrm{A}^{*}$ algoritmasının kullanıldığ1 öğrenilmiştir.

Bu bilgiler doğrultusunda işletmenin Yenişehir İlçesinde hizmet verdiği dokuz mahalle için ayrı ayrı en uygun rota bulunmuştur. Bu dokuz mahalle; Dumlupınar Mahallesi, İnönü Mahallesi, Piri Reis Mahallesi, Gazi Mahallesi, Aydınlıkevler Mahallesi, Palmiye Mahallesi, Menteş Mahallesi, Güvenevler Mahallesi ve Barbaros Mahallesidir. Şekillerde yer alan Gösterim Geçiş Sayısı bir sokaktan kaç kere geçildiğini göstermektedir ve geçiş sayısı arttıkça çizginin rengi koyulaşmaktadır. 
Şekil 3. Dumlupınar Mahallesi için Belirlenen En Kısa Yol

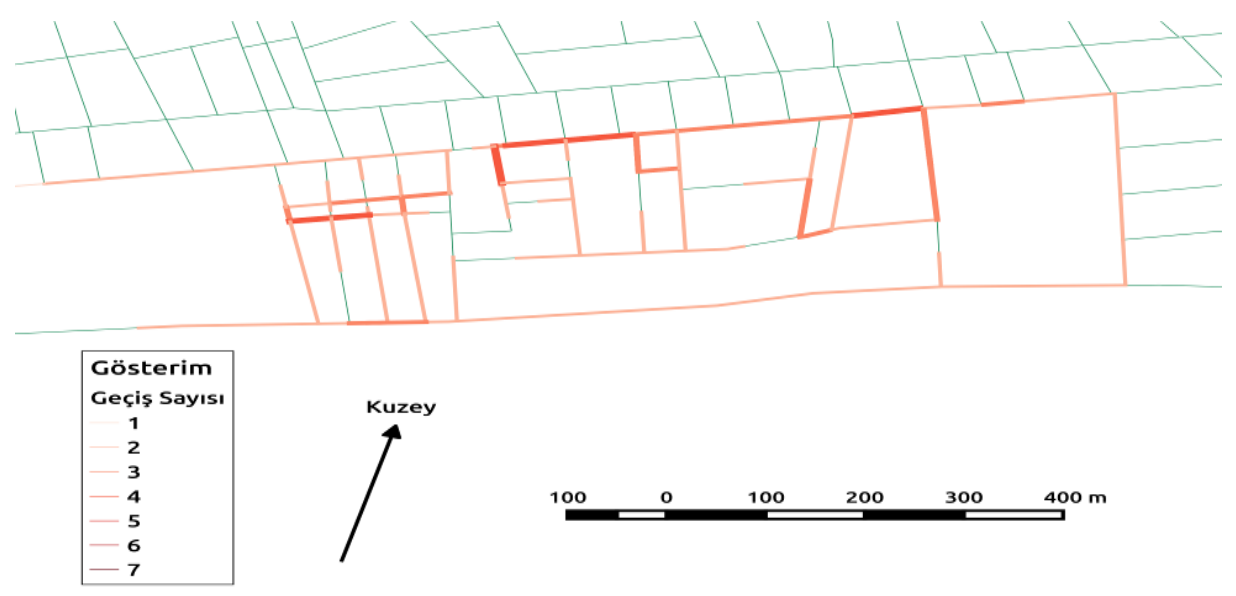

Şekil 3'te yer alan Dumlupınar Mahallesinde 1740 konut, 109 özel iş yeri, 4 okul, 2 alış veriş merkezi ve 128 kamu kurumu bulunmaktadır. Araç şekilde görülen rotayı takip ettiğinde toplamda $8.456,78$ metre yol almıştır.

\section{Şekil 4. Gazi Mahallesi Ị̧̇in Belirlenen En Kısa Yol}

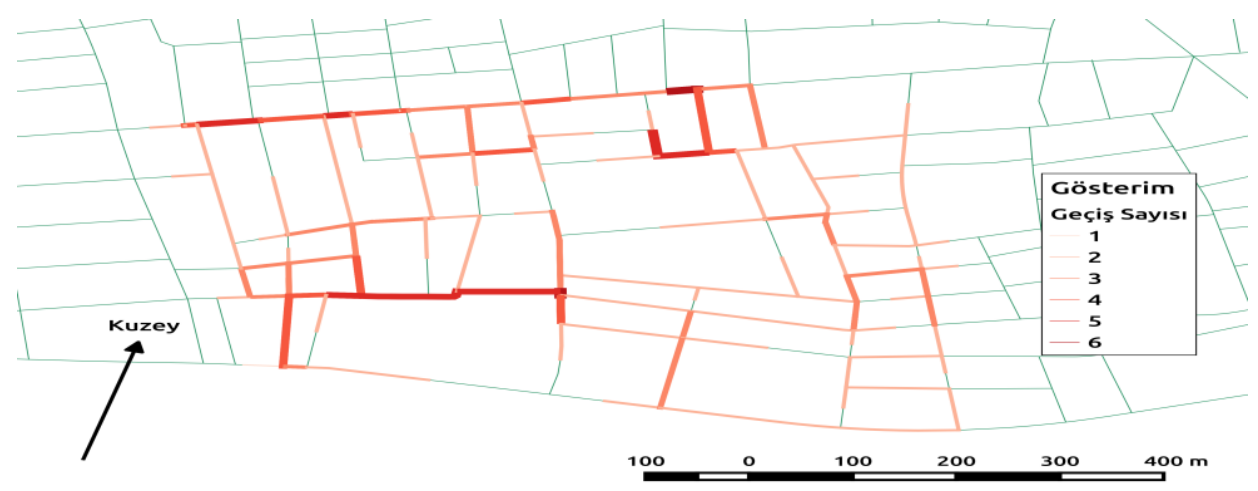

Gazi Mahallesinde 3823 konut, 265 özel iş yeri, 1 okul, 2 hastane, 2 otel ve 56 kamu kurumuna hizmet verilmektedir. Şekilde görülen rotayı takip ettiğinde aracın toplam kat ettiği yol 13.295,01 metre'dir. 


\section{Şekil 5. Güvenevler Mahallesi İçin Belirlenen En Kısa Yol}

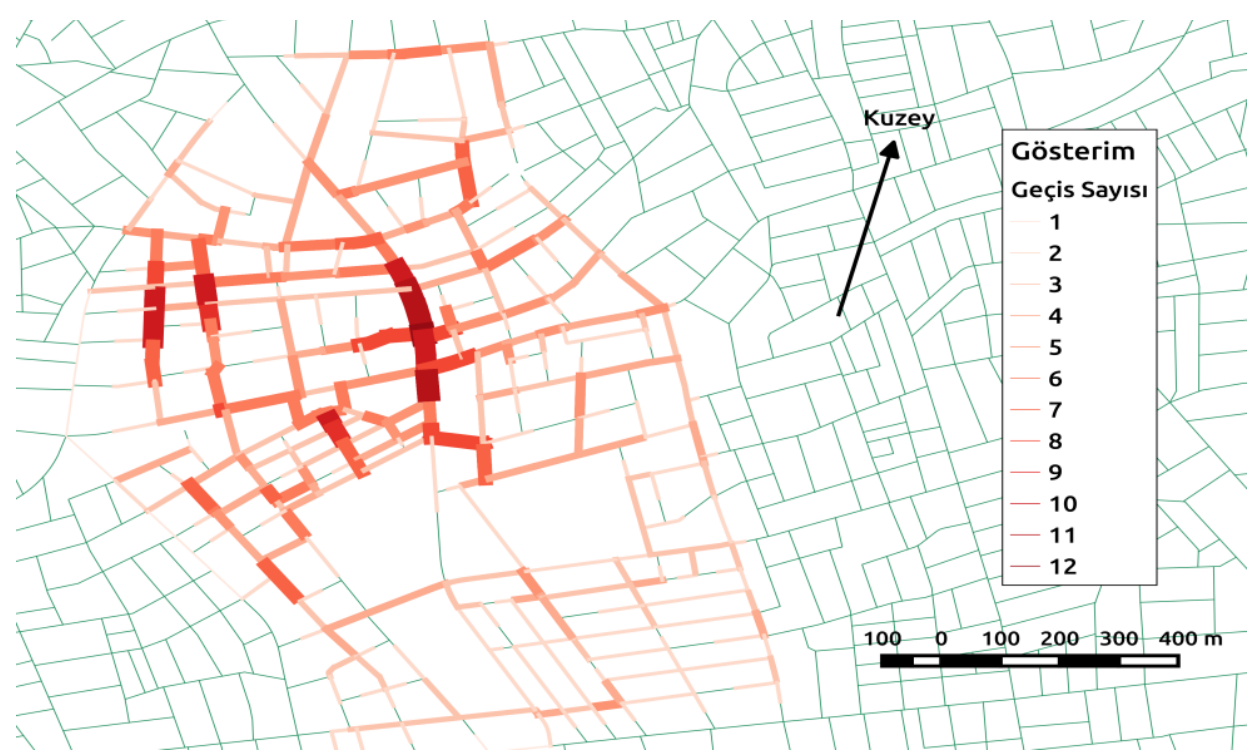

Güvenevler Mahallesinde ise 5844 konut, 465 özel iş yeri, 3 okul, 4 alış veriş merkezi, 3 hastane ve 2 kamu kurumuna hizmet verilmektedir ve toplamda 63.810,46 metre'lik mesafe kat etmektedir.

\section{Şekil 6. Aydınık Evler Mahallesi İçin Belirlenen En Kısa Yol}

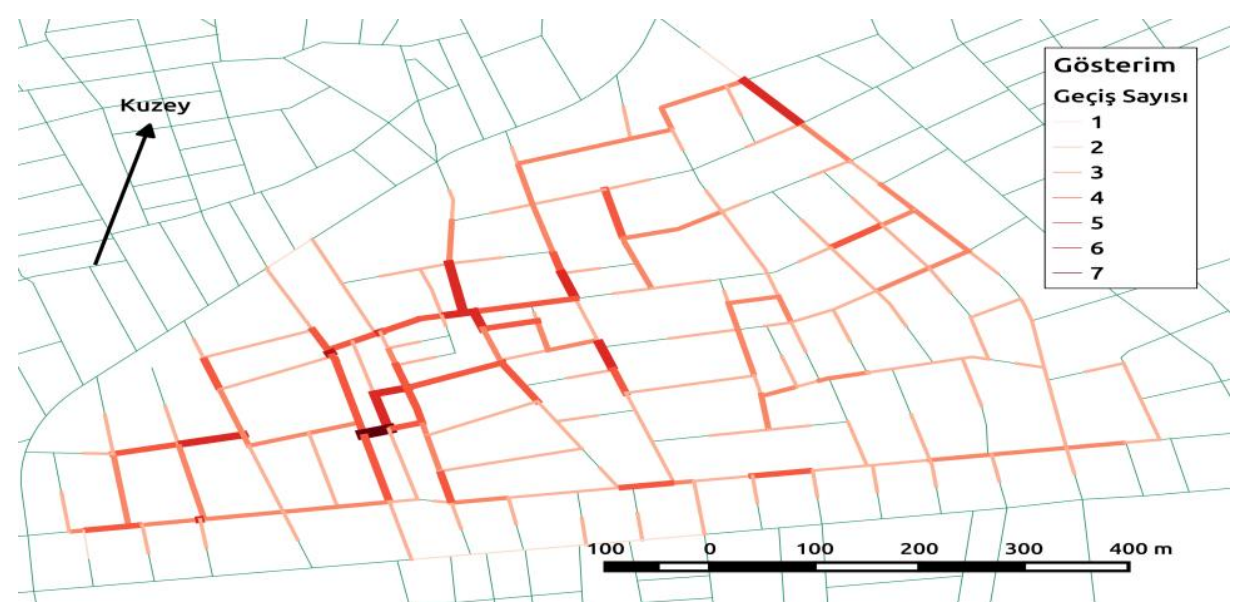

Aydınlık evler Mahallesinde 3185 konut, 194 özel iş yeri, 2 okul, 2 alış veriş̧ merkezi, 2 otel, 1 hastane ve 8 kamu kurumu bulunmaktadır. Belirlenen rota ile araç 19.889,18 metre yol almıştır.

Hacettepe University Journal of Economics and Administrative Sciences Vol 36, Issue 1, 2018 


\section{Şekil 7. Palmiye Mahallesi İçin Belirlenen En Kısa Yol}

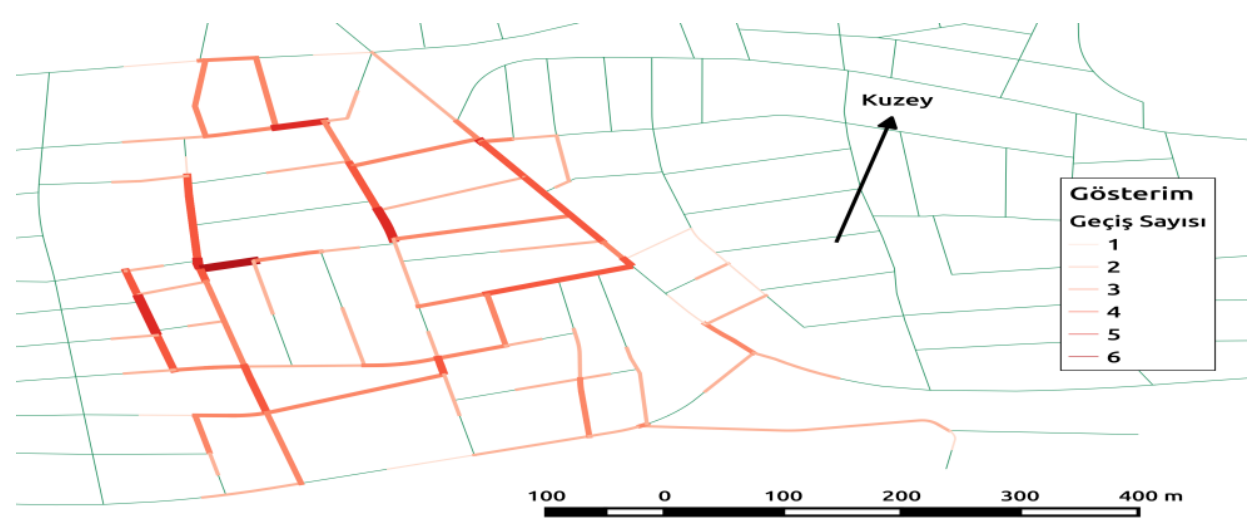

Palmiye mahallesinde ise 2900 konut, 410 özel iş yeri, 1 okul ve 5 kamu kurumu bulunmaktadır. Araç şekilde görülen rotayı takip ettiğinde toplamda 10.972,74 metre yol almıştır.

\section{Şekil 8. Menteş Mahallesi İçin Belirlenen En Kısa Yol}

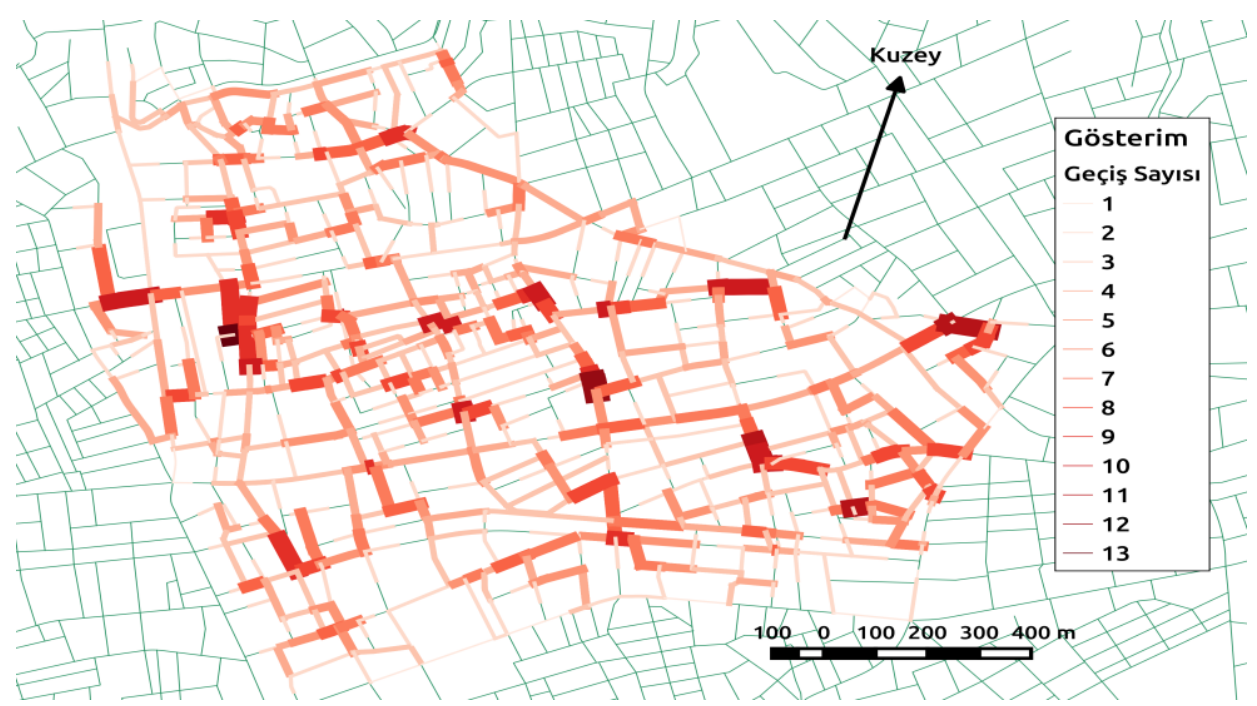

Menteş Mahallesinde 2984 konut, 100 özel iş yeri, 1 okul ve 9 kamu kurumuna sahiptir. Programdan elde edilen rotaya göre, araç Menteş Mahallesinde 121.432,6 metre yol kat etmektedir. 
Şekil 9. Barbaros Mahallesi İçin Belirlenen En Kısa Yol

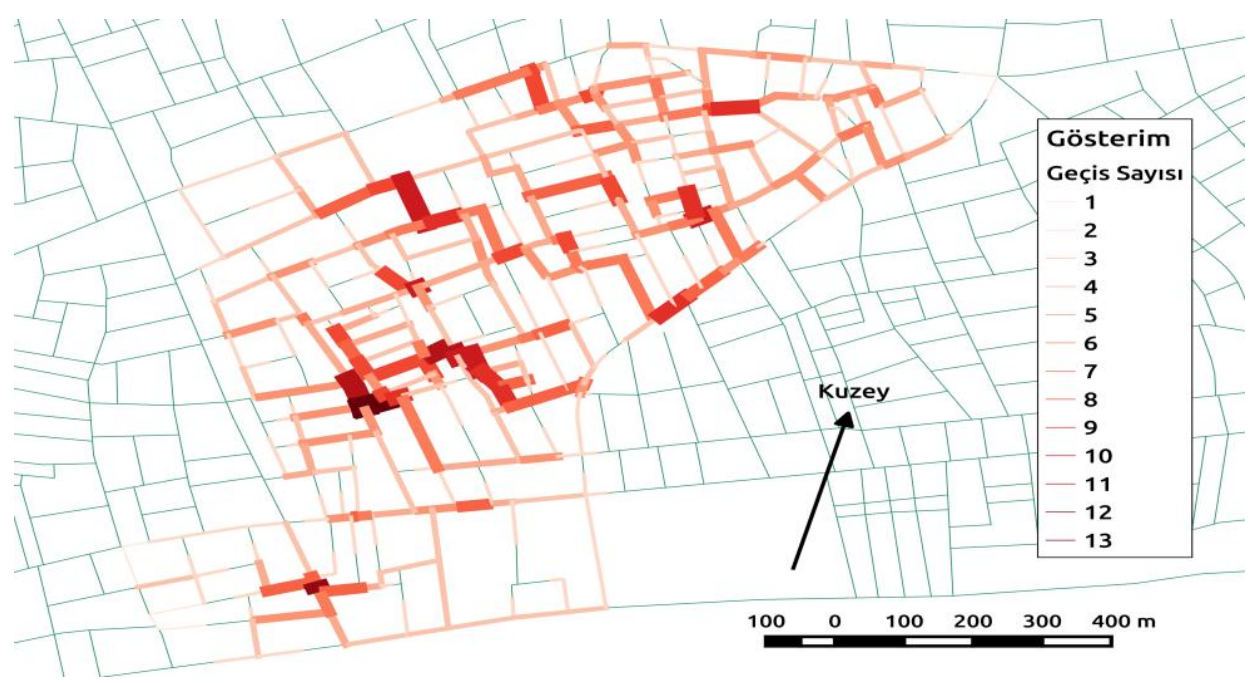

Barbaros Mahallesinde 3850 konut, 163 özel iş yeri, 2 okul, 1 hastane ve 17 kamu kurumu bulunmaktadır. Belirlenen rota ile toplamda 57.672,28 metre yol kat edilmektedir.

Şekil 10. Piri Reis Mahallesi İçin Belirlenen En Kısa Yol

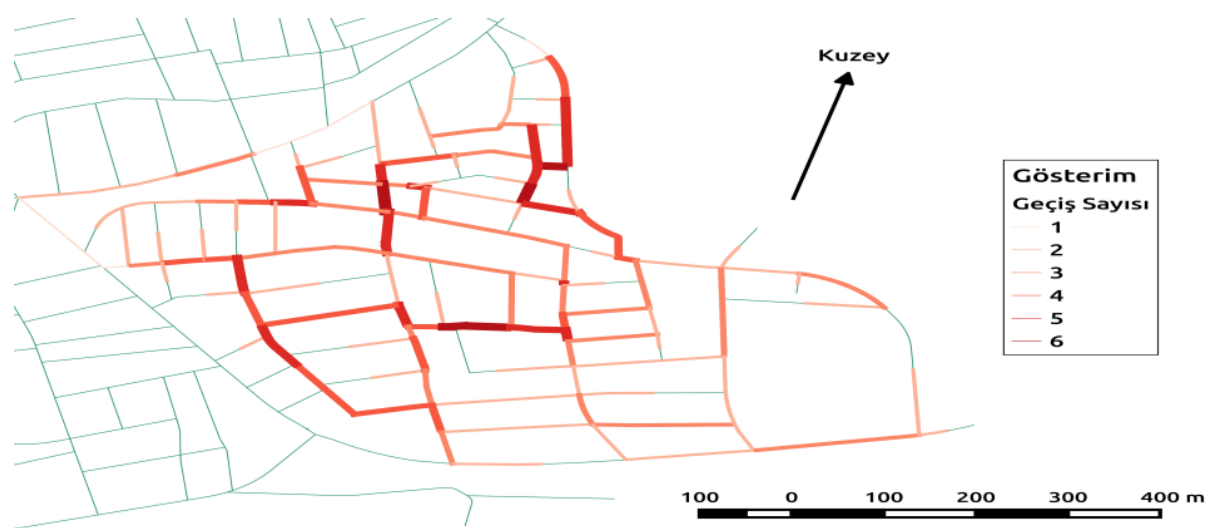

Piri Reis Mahallesinde 38 kamu kurumu, 3900 konut, 380 özel iş yeri, 1 okul ve 1 hastane bulunmaktadır. Araç şekilde görülen rotayı takip ettiğinde toplamda 17.789,12 metre yol almıştır. 


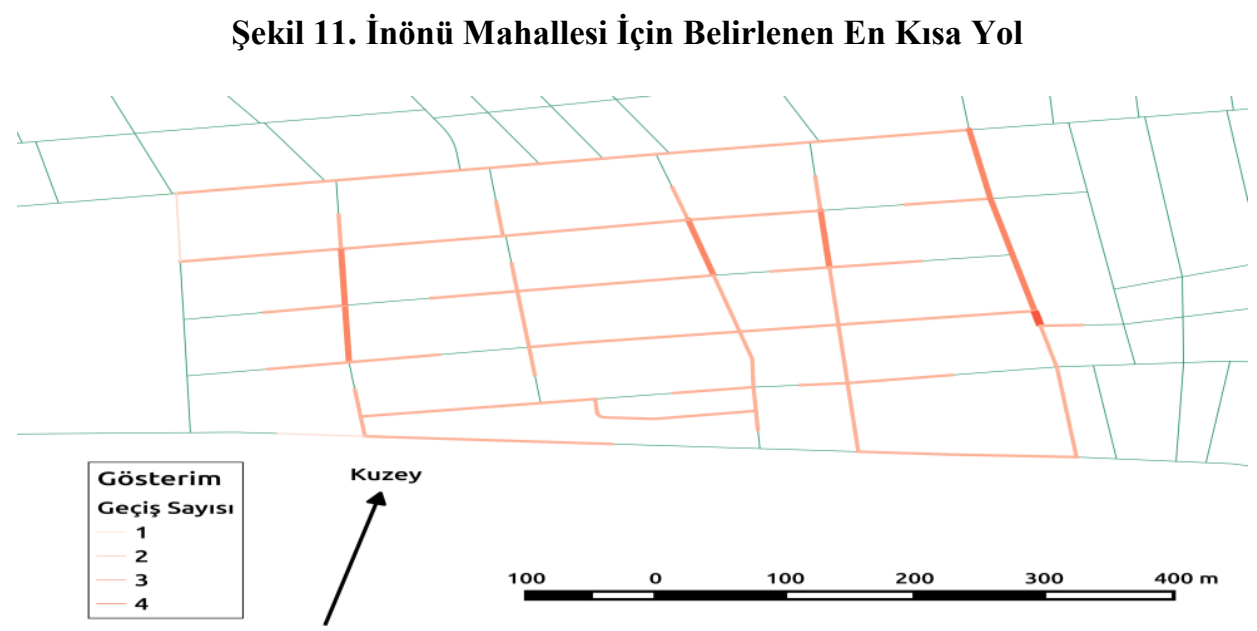

Şekil 11'de yer alan İnönü Mahallesinde 2986 konut, 259 özel iş yeri, 1 okul ve 2 kamu kurumu bulunmaktadır. Araç şekilde görülen rotayı takip ettiğinde toplamda $6.265,04$ metre yol almıştır.

\section{MEVCUT VE ÖNERILEN ROTALARIN PERFORMANS KARŞILAŞTIRILMASI}

Çalı̧̧maya konu olan firmanın araçlara hangi gün hangi mahalle ve/veya kurum/kuruluşlara gideceği bilgisini vermekte olduğu, mahalle içi toplama rotasını sürücünün inisiyatifine bırakıldığı daha önce belirtilmişti. Araçların hangi rotayı takip edeceği, sadece sürücünün inisiyatifine bırakılması sonucunda, araç sürücüsünün değişmesiyle birlikte rota da değişebilmekte, bu da firma açısından toplam kat edilen mesafelerdeki farkl11ıklardan dolayı maliyetler konusunda tutarsızlıklara neden olabilmektedir.

Çalı̧̧mamızda önerdiğimiz rotaların mevcut durumla karşılaştıııl-masının yapılabilmesi, ancak araç sürücüsünün takip edilerek hangi rotayı izlediğinin tespitine bağlı olması, uygulama açısından bazı olanaksızlıklar içermektedir. Firma ile yapmış olduğumuz görüşme sonucunda, rotalarını belirlediğimiz 9 mahalleden en küçüklerinden birisi olan İnönü Mahallesinde şu anki sürücüsüyle bir araya gelerek hangi rotayı izlediğini belirledik ve bu rotayı Şekil 12 'de yer alan harita üzerinde gösterdik. 


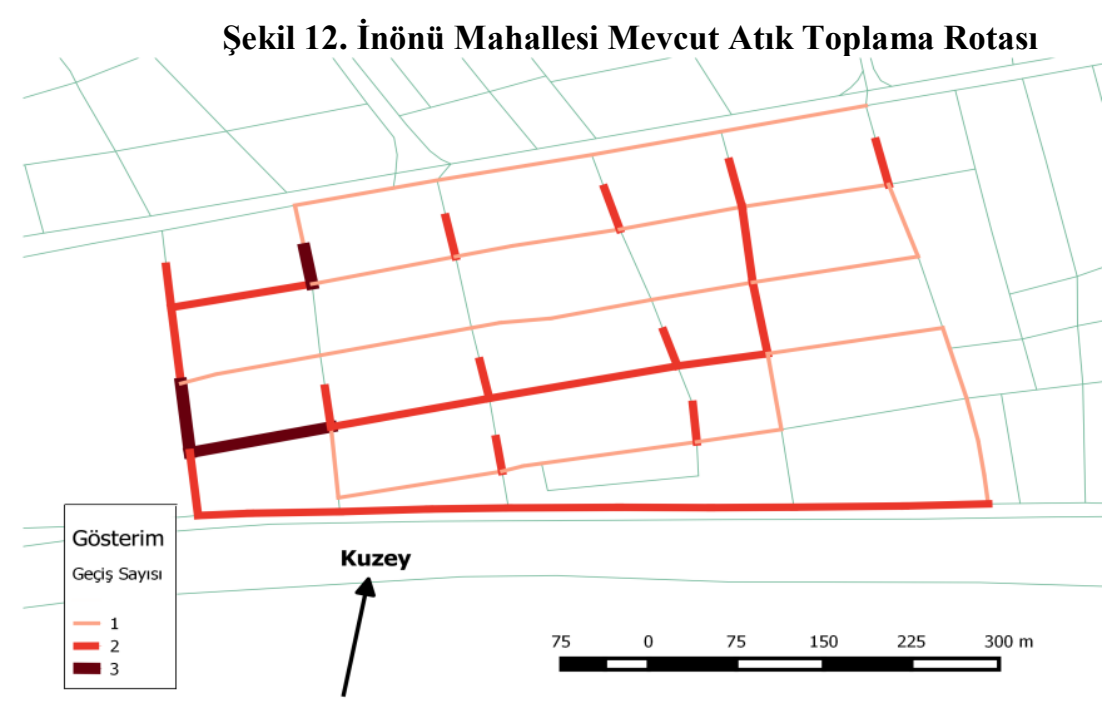

Araç, Şekil 12 'de görülen rotayı takip ettiğinde İnönü Mahallesinde toplamda 6.947,72 metre yol almıştır. Çalışmamızda bu mahalle için önerdiğimiz en kısa rota ile toplamda 6.265,04 metre yol kat etmektedir (Şekil 11). Elde edilen rota mevcut rotadan $\% 9.8$ daha kısadır.

Diğer mahalleler için sürücü insiyatifinde toplama yapılması, yüzölçümü büyüklüğü, sokak sayılarındaki fazlalık vb. gibi nedenlerden dolayı mevcut atık toplama rotaları belirlenememiştir.

Ancak burada belirtilmesi gereken konu, gvSIG programının Network eklentisinin "Shortest Path" modülünün araç rotalama problemlerinin çözümünde kullanılan En Kısa Yol Yönteminden farklı bir mantıkla çalışmakta olduğudur. Araç rotalama problemlerinde kullanılan en kısa yol yönteminde, rotanın başlangıç ve bitiş noktası model kurucu tarafindan belirlenmekte ve araçlar her durağa uğrama zorunluluğu olmadan en kısa yoldan bitiş noktasında ulaşmaya çalışmaktadır ve her noktadan en fazla bir kez geçmektedir. Ancak gvSIG programı ile hesaplanan en kısa yolda noktalar program tarafından belirlenmekte (üzerinde değişiklik yapılabilir yani program tarafından atanan bir nokta kaldırılabilir veya tanımlanmamış bir durak nokta konarak rotaya dahil edilebilir) ve program atılan ilk noktayı başlangıç noktası olarak tanımlamaktadır. Ayrıca en kısa yol hesaplanırken her durağa uğranılması şartı bulunmakla birlikte bir noktadan birden fazla kez geçebilmektedir. Aslında bu durum çalışma için istenen bir durumdur. Çünkü araçlar her mahalledeki her sokağa uğramak ve rotaları buna göre belirlenmek zorundadır. Ayrıca yolların yapısı (çıkmaz sokak, kavşak vs.) bir noktadan birden fazla geçilmeyi gerektirebilir. Burada yapılmak istenen, her mahalledeki her sokağa/noktaya uğranacak şekilde en kısa yolu belirlemektir. Bu 
yüzden bu durum çalışmanın araç rotalama problemi kısmı için varsayım olarak kabul edilmiştir.

\section{SONUÇ}

Yasal sınırlamalar ve yönetmelikler, müşterilerin çevreyle ilgili endişeleri ve işletmelerin çevreye karşı sosyal sorumlulukları gibi farklı sebeplerle işletmeler tarafından uygulanan tersine lojistik, kullanılmış ürünlerin yeniden değerlendirilme potansiyellerine dikkat çekmek amacıyla ortaya çıkmışıtır. Tersine lojistik, geri kazanımı sağlanmış ürünler için pazar bulmanın zor olması, ileri lojistiğin tam simetriği olmadığı için yapısal sorunların olması, üreticiler için hammadde bulma zorluğunun olması ve geri dönüş akışında kalite, miktar ve zamanlamanın belirsiz olması gibi özelliklere sahiptir. Bu yüzden tersine lojistik faaliyetleri oldukça karmaşıktır ve uygulanması zordur.

$\mathrm{Bu}$ çalışmada ise, ambalaj atığı toplayıcısı bir işletmenin araçlarının toplama yaptı̆̆ı noktaları en kısa yoldan dolaşmasını sağlamak için araç rotalama problemi en kısa yol yöntemi ile çözülmüştür. Problemin çözümünde özellikle Açık Kaynak Kodlu CBS yazılımları tercih edilerek, OpenJUMP ve gvSIG programlarından yararlanılmıştır. Çalışmada belirlenen rotalar işletme tarafindan belirlenen araçlara atanan mahallelere ve diğer uğranılacak yerlere göre yapılmıştır. İşletmede araçların günlük takip ettiği rotalar normalde araçların şoförleri tarafından belirlendiği için şoförlerin inisiyatifinde bir rota izlenilmektedir. Bu yüzden bu çalışmanın işletmeye en az maliyetli (en kısa mesafeli) bir rota takip etmesi için yardımcı olacağı düşünülmektedir. Kullanılan CBS yazılımlarının ücretsiz ve Açık Kaynak Kodlu olması nedeniyle kullanılan rotalama işlemi farklı işletmeler için de kolaylıkla uygulanabileceği gibi araştırmacılar ve akademisyenler tarafından farklı uygulama alanlarında (kuruluş yeri seçimi, depo seçimi vs.) da kullanılabileceği düşünülmektedir. Çalışmanın bu yönde ortaya koyduğu katkı özellikle önemlidir.

İleride yapılacak çalışmalar açısından ise değişik senaryoların da denenerek sadece mahalleye göre değil farklı bölgelere ayrılarak toplam kat edilen mesafenin kısaltılıp kısaltılmadığı ölçülebilir. Ancak, atıkların toplandığı mekânların farklılık göstermesi (mesken, özel iş yeri, okul, kamu kurumu, hastane, AVM gibi) ve toplanan atık miktarları farklılık gösterdiği için bu durum rotaların çizilmesinde ayrıca dikkate alınabilir. Ayrıca çalışmaya arz-talep kısıtları, araçlara hız-kapasite kısıtları gibi kısıtlar konularak da farklı uygulamalar yapılabilir. 
CINGÖZ, GÜRGEN, BEYHAN | Determination of the Routes of Waste Collection Vehicles...

\section{KAYNAKÇA}

Agrawal, S., R.K. Singh, Q. Murtaza (2015), “A Literature Review and Perspectives in Reverse Logistics", Resources, Conservation and Recycling, 97, 76-92.

Alevkayal1, Ç. (2012), Ege Üniversitesi için bir Kampüs Coğrafi Bilgi Sistemi Tasarımı, yayımlanmamış yüksek lisans tezi, İzmir: Ege Üniversitesi/Sosyal Bilimler Enstitüsü.

Apaydın, O., E. Arslankaya, Y. Avsar, M.T. Gönüllü (2004), "GIS Supported Optimization of Solid Waste Collection in Trabzon”, Sigma, 4, 249-254.

Bae, H., I. Moon (2016), "Multi-Depot Vehicle Routing Problem with Time Windows Considering Delivery and Installation Vehicles", Applied Mathematical Modelling, 40(13), 6536-6549.

Banar, M., A. Özkan, M. Altan, C. Ayday (2008), "Planning of the Healthcare Waste Collection Routes in Eskişehir by Using Gis", Anadolu Üniversitesi Bilim ve Teknoloji Dergisi, 9(1), 87-96.

Beyhan, B., B. Belge, F. Zorlu (2010), “Özgür ve Açık Kaynak Kodlu Masaüstü CBS Yazılımları Üzerine: Karşılaştırmalı ve Sistemli Bir Değerlendirme”, Harita Dergisi, 143, 45-61.

De Brito, M.P., R. Dekker (2002), "Reverse logistics - a framework", Econometric Institute Report EI 2002-38, 1-39.

Dethloff, J. (2001), "Vehicle Routing and Reverse Logistics: The Vehicle Routing Problem with Simultaneous Delivery and Pick-Up”, OR Specktrum, 23(1), 79-96.

Düzakın, E., M. Demircioğlu (2009), “Araç Rotalama Problemleri ve Çözüm Yöntemleri”, Çukurova Üniversitesi İktisadi ve İdari Bilimler Dergisi, 13(1), 68-87.

Ekşioğlu, B., A.V. Vural, A. Reisman (2009), “A Vehicle Routing Problem; A Taxonomic Review”, Computers and Industrial Engineering, 57(4), 1472-1483.

Erol, V. (2006), Araç Rotalama Problemleri İçin Populasyon ve Komşuluk Tabanlı Metasezgisel Bir Algoritmanın Tasarımı ve Uygulaması, yayımlanmamış yüksek lisans tezi, İstanbul: Yıldız Teknik Üniversitesi, Sosyal Bilimler Enstitüsü.

Fazal, S. (2008), GIS basic, New Delhi: New Age International Publisher.

Fleischmann, M., J.M. Bloemhof-Ruwaard, R. Dekker, van der E. Laan, van Nunen JAEE, van L.N. Wassenhove (1997), "Qantitative Models for Reverse Logistics: A Review", European Journal of Operational Research, 103, 1-17.

Fleischemann, M., H.R. Krikke, R. Dekker, S.D.P. Flapper (2000), “A Characterization of Logistics Network For Product Recovery”, Omega, 28, 653-666.

Fleischemann, M. (2001), Reverse Logistics Network Structures and Design, (No. ERS-2001-52LIS) ERIM Report Series Research in Management.

Ghose, M.K., A.K. Dikshit, S.K. Sharma (2006), “A GIS Based Transportation Model for Solid Waste Disposal-A Case Study on Asansol Municipality”, Waste Management, 26(11), 1287-1293.

Güvez, H., M. Dege, T. Eren (2012), “Kırıkkale'de Araç Rotalama Problemi ile Tıbbi Atıkların Toplanması", International Journal of Engineering Tesearch and Development, 4(1), 41-45. 
Hart, P. E., N.J. Nilsson, B. Raphael (1968), "A Formal Basis for the Heuristic Determination of Minimum Cost Paths". IEEE Transactions on Systems Science and Cybernetics SSC4, 4 (2), 100-107.

Kaçtıoğlu, S., Ü. Şengül (2010), “Erzurum Kenti Ambalaj Atıklarının Geri Dönüşümü İçin Tersine Lojistik Ağı Tasarımı ve Bir Karma Tamsayılı Programlama Modeli”, Atatürk Üniversitesi İktisadi ve İdari Bilimler Fakültesi Dergisi, 24(1), 89-112.

Kalkanc1, Ç. (2009), Coğrafi Bilgi Sistemleri Destekli Üretim ve Lojistik Optimizasyonu ve Asfalt Sektöründe Bir Uygulama, yayımlanmamış yüksek lisans tezi, İstanbul: İstanbul Üniversitesi Fen Bilimleri Enstitüsü.

Kassem, S., M. Chen (2013), "Solving Reverse Logistics Vehicle Routing Problems with Time Windows", International Journal of Advanced Manufacturing Technology, 68(1-4), 5768.

Kuşçu, Ö. (2009), Araç Rotalama Sistemlerinde Sezgisel Yöntem, yayımlanmamış yüksek lisans tezi, Isparta: Süleyman Demirel Üniversitesi/Sosyal Bilimler Enstitüsü,

Li, J., P.M. Pardalos, H. Sun, J. Pei, Y. Zhang (2015), "Iterated Local Search Embedded Adaptive Neighborhood Selection Approach for the Multi-Depot Vehicle Routing Problem with Simultaneous Deliveries and Pickups", Expert Systems with Applications, 42(7), 35513561.

Li, H., J. Yuan, Lv, T., X. Chang (2016), “The Two-Echelon Time-Constrained Vehicle Routing Problem in Linehaul-Delivery Systems Considering Carbon Dioxide Emissions", Transportation Research Part D: Transport and Environment, 49, 231-245.

Liu, R., X. Xie, V. Augusto, C. Rodriguez (2013), "Heuristic Algorithms for a Vehicle Routing Problem with Simultaneous Delivery and Pickup and Time Windows in Home Health Care", European Journal of Operational Research, 230(3), 475-486.

Madankumar, S., C. Rajendra (2016), "Mathematical Models for Green Vehicle Routing Problems with Pickup and Delivery: A Case of Semiconductor Supply chain", Computers \& Operations Research.

Montané, F.A.T., R.D. Galvao (2006), “A Tabu Search Algorithm for the Vehicle Routing Problem with Simultaneous Pick-Up and Delivery Service”, Computers \& Operations Research, 33(3), 595-619

Nayati, M.A.K. (2008), School Bus Routing and Scheduling using GIS, University of Gavle, Sweden: Departament of Technology and Built Environment.

Pishvaee, M.S., K. Kianfar, B. Karimi (2010), "Reverse Logistics Network Design Using Simulated Annealing", The International Journal of Advanced Manufacturing Technology, 47(1-4), 269-281.

Rego, C. (2001), "Node Ejection Chains for the Vehicle Routing Problem: Sequential and Parallel Algorithms", Parallel-Computing, 27, 201-222.

Rogers, D.S., R.S. Tibben-Lembke (1998), Going Backwards: Reverse Logistics Trends and Practices, Pittsburg PA: Reverse Logistics Executive Council. 
CINGÖZ, GÜRGEN, BEYHAN | Determination of the Routes of Waste Collection Vehicles...

Seo, W.J., S.H. Ok, J.H. Ahn, S. Kang, B. Moon (2009), “An Efficient Hardware Architecture of the A-star Algorithm for the Shortest Path Search Engine", in INC, IMS and IDC, 2009. NCM'09, Fifth International Joint Conference on, IEEE, pp. 1499-1502.

Soysal, M., J.M. Bloemhof-Ruwaard, T. Bektaş (2015), “The Time-Dependent Two-Echelon Capacitated Vehicle Routing Problem with Environmental Considerations", International Journal of Production Economics, 164, 366-378.

Tasan, A.S., M. Gen (2012), “A Genetic Algorithm Based Approach to Vehicle Routing Problem with Simultaneous Pick-Up and Deliveries”, Computers\&Industrial Engineering, 62(3), 755-761.

Toth, P., D. Vigo (2001), Vehicle Routing Problem, United States of America: Siam.

Toth, P., D. Vigo (2002), "Models, Relaxations and Exact Approaches for the Capacitated Vehicle Routing Problem”, Discrete Applied Mathematics, 123(1), 487-512.

Wassan, N.A., A.H. Wassan, G. Nagy (2008), “A Reactive Algorithm for the Vehicle Routing Problem with Simultaneous Pickups and Deliveries", Journal of Combinatorial Optimization, 15(4), 168-386.

Zchariadis, E.E., C.T. Kiranoudis (2011), “A Local Metaheuristic Algorithm for the Vehicle Routing Problems with Simultaneous Picks-Up and Deliveries", Expert Systems with Applications, 38, 2717-2726. 